\title{
Measuring student teachers' basic psychological needs
}

\author{
Citation for published version (APA):
}

Vermeulen, M., Castelijns, J., Koster, B., \& Kools, Q. (2012). Measuring student teachers' basic psychological needs. Journal of Education for Teaching, 38(4), 453-467. https://doi.org/10.1080/02607476.2012.688556

\section{DOI:}

10.1080/02607476.2012.688556

Document status and date:

Published: 01/08/2012

Document Version:

Peer reviewed version

\section{Document license:}

CC BY-SA

Please check the document version of this publication:

- A submitted manuscript is the version of the article upon submission and before peer-review. There can be important differences between the submitted version and the official published version of record. People interested in the research are advised to contact the author for the final version of the publication, or visit the DOI to the publisher's website.

- The final author version and the galley proof are versions of the publication after peer review.

- The final published version features the final layout of the paper including the volume, issue and page numbers.

Link to publication

\section{General rights}

Copyright and moral rights for the publications made accessible in the public portal are retained by the authors and/or other copyright owners and it is a condition of accessing publications that users recognise and abide by the legal requirements associated with these rights.

- Users may download and print one copy of any publication from the public portal for the purpose of private study or research.

- You may not further distribute the material or use it for any profit-making activity or commercial gain

- You may freely distribute the URL identifying the publication in the public portal.

If the publication is distributed under the terms of Article 25fa of the Dutch Copyright Act, indicated by the "Taverne" license above, please follow below link for the End User Agreement:

https://www.ou.nl/taverne-agreement

Take down policy

If you believe that this document breaches copyright please contact us at:

pure-support@ou.nl

providing details and we will investigate your claim.

Downloaded from https://research.ou.nl/ on date: 26 Apr. 2023 
Measuring student teachers' basic psychological needs

Marjan Vermeulen (corresponding author)

Open Universiteit Nederland, Valkenburgerweg 177, 6419AT Heerlen, marjan.vermeulen@ou.nl

KPC-Groep

P.O.Box 482, 5201 AL 's-Hertogenbosch, The Netherlands $\underline{\text { m.vermeulen@kpcgroep.nl }}$

Jos Castelijns

KPC-Groep

P.O.Box 482, 5201 AL 's-Hertogenbosch, The Netherlands

j.castelijns@kpcgroep.nl

De Kempel Teacher Education Institute

Deurneseweg 11, 5709 AH Helmond, The Netherlands

j.castelijns@kempel.nl

Interactum Federation of Teacher Education Institutes

P.O. Box 2511, 3500 GM Utrecht, The Netherlands

j.castelijns@interactum.nl

Bob Koster

Interactum Teacher Education

P.O. Box 2511, 3500 GM Utrecht, The Netherlands 
Teacher educator at COLUU Utrecht University,

P.O. 80127, 3508 TC Utrecht, The Netherlands. b.koster@uu.nl

\section{Quinta Kools}

Interactum Teacher Education

P.O. Box 2511, 3500 GM Utrecht, The Netherlands

Teacher education institute of Fontys University of Applied science,

PO Box 90900, 5000 LA Tilburg, the Netherlands.

q.kools@fontys.nl

Number of words: 5.779 


\begin{abstract}
In the Self-Determination Theory (SDT) basic psychological needs for relatedness, autonomy and competence are distinguished. Basic psychological need fulfilment is considered to be critical for human development and intrinsic motivation. In the Netherlands, the concept of basic psychological need fulfilment is introduced in the curricula of many teacher education institutes. In five teacher education institutes, study coaches use a Dutch version of the Basic Psychological Needs Scale (BPNS), to collect data to be used in a discussion with student teachers about their intrinsic motivation for a specific part of the teacher education course. On the basis of the outcomes of this discussion, study coaches and student teachers derive consequences for day to day practice in their classrooms. The data were also used to establish whether the theoretical distinction between three basic psychological needs is found in this sample of student teachers in the Netherlands.

The results show that the constructs of relatedness, autonomy and competence are found and can be measured by using a 14-item five-point scale, partly based on the original BPNS, and partly on new items that focus on different sources of perceived need fulfilment, namely teacher education in general, the study coach and fellow students.
\end{abstract}

Key words: relatedness; autonomy; competence; intrinsic motivation; self-regulation; student teacher . 


\section{Measuring student teachers' basic psychological needs}

\section{Introduction}

In the second half of the nineties of the last century, the Self-Determination Theory (Deci and Ryan 1985; Deci and Ryan 2000; Deci and Ryan 2002; Deci and Ryan 2008) was introduced in schools in the Netherlands. Especially the importance of the basic psychological needs for relatedness, competence and autonomy with regard to the development and well-being of students in primary and secondary education was emphasised (see for example Stevens 1997). As a result of the attention that was given to these concepts, many primary and secondary schools in the Netherlands claim they take the students' basic psychological needs into account when shaping daily practice in their classrooms.

Not only in primary and secondary schools but also in teacher education in the Netherlands the concept of the basic psychological needs is widespread. Student teachers are expected to acquire competencies that enable them to tune into the students' basic psychological needs effectively. Furthermore in the curriculum, taking the student teachers' basic psychological needs into consideration is emphasised as a major pedagogic principle (Evelein, Korthagen and Brekelmans 2008). This focus on student teachers' basic psychological needs is connected to a growing interest in their motivation, not only in the Netherlands but also abroad (Filak and Sheldon 2003; Roth, Assor, Kanat-Mayon and Kaplan 2007) and is often linked to the shortage and the attrition of (student) teachers (Roness and Smith 2010).

In the Self-Determination Theory, the basic psychological needs are postulated as innate and universal. Fulfilment of these needs is considered to be crucial for human wellbeing and development in general. For the fulfilment of these needs, people depend on the interaction with other people. Effective interaction between people and their social context 
results in need fulfilment, and consequently in people's well-being, development, intrinsic motivation and self-regulation (Deci and Ryan 2002; Deci and Vansteenkiste 2004). Ineffective interaction thwarts need fulfilment, which has a negative effect on well-being and other emotional factors.

In the last decades, the Self-Determination Theory provided a theoretical framework for research in various domains like education, medical care (Williams, McGregor, King, Nelson and Glasgow 2005), sports (Hagger and Chatzisarantis 2007), work (Baard, Deci and Ryan 2004) and psychotherapy, (Ryan, Lynch, Vansteenkiste and Deci 2010), resulting in many publications that contributed to the further development and refinement of the theory and its concepts. Research also yielded many questionnaires to measure basic psychological needs and linking concepts like intrinsic motivation and self-regulation, in particular in adults and adolescents (see www.psych.rochester.edu/STD).

The study we report on here is part of a larger project called 'Collaborative innovation of schools and teacher education' (names of authors deleted to maintain the integrity of the review process). One of the project's starting points is the ambition to develop a classroom climate that meets the student teachers' basic psychological needs. The assumption is that this will enhance their intrinsic motivation and self-regulation as well as their academic achievement. A strategy is developed which includes the collection of data about student teachers' perceived basic psychological need-fulfilment in the teacher education course they take. For this purpose a Dutch version of Deci and Ryans Basic Psychological Needs Scales (BPNS, see www.psych.rochester.edu/STD) is used. The teacher and the student teachers jointly discuss the data collected in their own class, make their collective interpretations explicit and derive consequences for daily practice in the course they take. This strategy is based on the social-constructivist concept of joint construction of meaning by members of a group (Gough 2008; Putnam 2010). Collective construction of meaning assumes that 
individual and therefore subjective members' perspectives are combined into a collective and intersubjective one (Guba and Lincoln 1989).

Although the data prove to be useful in a practical way, namely to provide an informed basis for classroom discussion, they also raise a theoretical question: To what extend do data with regard to perceived need fulfilment, collected in a sample of Dutch student teachers, support the theoretical distinction between the basic psychological needs for relatedness, autonomy and competence? The assumption is that if basic psychological needs are universal indeed, as claimed by Deci and Ryan, those can be expected to be found in a sample of student teachers in the Netherlands. Answering this question is important from a theoretical point of view, because it either supports Deci and Ryans theoretical claim, or it yields alternative hypotheses. Answering this question is also important from a practical angle, since teacher educators, study coaches and trainers, who strive to tune into their student teachers' needs, need to know which needs actually can be distinguished.

\section{Theory}

The importance of psychological basic needs for the development and well-being of people is extensively described and well-documented in the Self-Determination Theory (Deci and Ryan 1985; Deci and Ryan 2000; Ryan and Deci 2000). This theory states that people by nature are active organisms that are, by nature, oriented to psychological development. Deci and Ryan (2002) define psychological development in terms of integration of psychological elements (thinking, feeling and acting) and people's integration or effective interaction with their (social) context. Psychological development is assumed to be propelled by people's striving for fulfilment of their basic psychological needs for relatedness, competence and autonomy. The concept of relatedness refers to people's need to feel connected with other people, to give and receive love, care, affection and friendship. Competence refers to people's need to 
perceive themselves as effective in their interaction with their physical and social context. People who feel competent, perceive themselves as able to influence their environment effectively and to realise valuable output through their own actions. Competence is strongly related to self-efficacy (Bandura 1997; Bandura and Schunk 1981). Schunk and Pajares (2007) define self-efficacy as one's perceived capabilities to learn of perform behaviours at designated levels. Self-efficacy refers to the perception of compentence in relation to a specific (academic) task.

Autonomy, refers to people's need for self-regulation (Ryan and Deci 2004; Ryan and Deci 2006). The concept is described by Deci and Ryan (2000) as 'the organismic desire to self-organize experience and behaviour and to have activity be concordant with one's integrated sense of self' (p. 231; see also Ryan 1995; Sheldon and Elliot 1998). Autonomy has it's origin in people's interaction with their social context where they adopt external values and regulations. This phenomenon is described as a process of internalisation (Ryan and Connell 1989). Values and regulations that originally are external, are being internalised by individuals, and finally perceived by them as their own ones (Deci and Ryan 2000; Vansteenkiste, Smeets, Soenens, Lens, Matos and Deci 2010). Self- regulation means that individuals direct their own behaviour on the basis of these internalised values and regulations. They perceive the locus of causality of their behaviour as internal to them.

Deci and Ryan connect the self-regulation to intrinsic motivation (Ryan and Deci 2000). Activities voluntarily undertaken by people, without any reward or pressure from their environment, are self-regulated. People perceive the locus of causality of intrinsically motivated behaviour as internal to them. They carry out these activities because they find them interesting or because they think they are important (Deci 1975). Lepper, Greene and Nisbett (1973) point out that extrinsic rewards (reinforcements) even can undermine intrinsic motivation (see also Kohn 1999). People's intrinsic motivated behaviour is propelled by their 
need to perceive themselves as competent and autonomous. Vansteenkiste, Lens and Deci (2006) show that intrinsic goal framing produces deeper engagement in learning activities, better conceptual learning and higher persistence in learning activities than external or nogoal framing. They theorise that intrinsic goals are more directly linked to the satisfaction of the basic psychological needs for relatedness, competence and autonomy (see also Vansteenkiste, Soenens, Verstruyf and Lens 2009)

The Self-Determination Theory emphasises that under certain circumstances, like rejection, over asking or excessive control, people's development can be thwarted or devitalised (see Martens 2007). Because people, by nature, strive for the fulfilment of their basic psychological needs, they may react by using defensive of self-protective strategies that become manifest as antisocial or self-centred behaviour, evoking more rejection and control from their social environment. Functional and non-functional interactions between people and their social context have a tendency to repeat themselves. Consequently, certain patterns of interaction arise. These patterns show on the one hand how people exert an influence on their social context in providing support and need fulfilment and, on the other hand how this need fulfilment is perceived by others and influences their behaviour.

Deci and Ryan (2000) point out that a healthy psychological development asks for the fulfilment of each of the basic psychological needs.

\section{Method}

This study's aim is to find out whether the perceived basic psychological needs for relatedness, competence and autonomy can be found in a sample of Dutch student teachers participating in a course for primary teacher education. To answer this question, a questionnaire is developed and administered by 271 (2008) and 222 (2009) student teachers. A confirmative factor analysis (Oost 1999; Garson 2007) is used to find out whether a 
structure with three factors, referring to the need for relatedness, competence and autonomy respectively, emerges from the data.

\section{Questionnaire}

The original BPNS consists of three scales that measure basic need fulfilment in personal relations, at work and in live in general. Because the first two scales consist of too many items which are irrelevant for student teachers (for example: 'I feel like I can make a lot of inputs in deciding how my job gets done' and 'When I am with xxx, I feel loved and cared about'), the general version of the BPNS is chosen for translation.

The original general version of the BPNS consists of 21 seven point items. Scoring alternatives vary from 1 (not al all true) to 7 (very true). The scale consists of three subscales, namely autonomy (seven items), competence (six items) and relatedness (eight items). The original BPNS-items are phrased in general terms of how respondents perceive need-

fulfilment in 'their life' or by 'people they know'. Because our study concerns need fulfilment within the context of teacher education, the items of the BPNS are adjusted accordingly. Schuman (1996) points out that context specificity of the items contributes to the reliability of the instrument. In the adapted version, 'life' is translated into 'teacher education course', and 'people' are made more specific in terms of 'the study coach' or 'fellow students'.

Furthermore, many of the original items are phrased in terms of feelings (i.e. 'I generally feel free to express my ideas and opinions'). Because of differences in culture (quite opposite to the US, in the Netherlands people often are fairly reticent about expressing their feelings), some items are rephrased in terms of perceptions (i.e. 'In the teacher education course, I can express my opinions freely').

In the context of teacher education, the distinction between the teacher educator or study coach, fellow student teachers and teacher education in general as sources of need-fulfilment 
seems relevant. So, the original number of 21 items is extended to 52 items in order to gain information about these different sources (e.g. 'The study coach offers me positive feedback', 'If we co-operate, my fellow students offer me positive feedback' and 'In teacher education, I acquire relevant new skills').

Most Dutch student teachers are familiar with filling in questionnaires concerning student satisfaction and evaluation of the course they take for purposes of quality management. Student evaluation of courses is obligatory for teacher education institutes in the Netherlands. Most of the questionnaires that are used for this purpose have five point scales. For that reason the original seven point scale is changed into a five point scale.

\section{Respondents}

During the period May-July 2008 the questionnaire is filled in by 271 student teachers in 5 different teacher education institutes (see Table 1). A second cohort of 222 different students from the same institutes filled in the questionnaire during spring 2009. The number of student teachers that are registered in these institutes vary from 650 to 1500 . Some of these institutes are located in cities and have mixed populations regarding culture and native language, some are situated in rural areas and have more homogenous populations.

The procedure is as follows. The study coaches handed out copies in their own classes and gave the student teachers instructions on how to fill them in. Because the questionnaire is administered during the lessons, the response is almost $100 \%$. Because of the initial practical aims of the project 'Collaborative learning in schools and teacher education', the respondents don't make up a representative sample of primary student teachers in the Netherlands. Given the research question (To what extend do data with regard to perceived need fulfilment, collected from a sample of Dutch student teachers, support the theoretical distinction between 
the basic psychological needs for relatedness, autonomy and competence) the selectiveness of the sample is considered to be irrelevant.

\section{INSERT TABLE 1 HERE}

\section{Method of analysis}

Based on Deci and Ryans theory, three latent variables (i.e. relatedness, autonomy and competence) can be hypothesised. Latent variables are hypothetical factors which are assumed to be found in the observed variables (Garson 2007). To statistically test a theoretical model, different methods can be used (Hox 1999). Because the items are translated and made more specific for student teachers, an exploratory method like a principal component analysis with varimax rotation (Garson 2007; Hox 1999; Reise, Widaman and Pugh 1993) is appropriate.

Deci and Ryan's model is tested stepwise, using PASW Statistics 18. The first step is a principal component analysis of the 21 translated items. Based on the results, a decision is made on the second step. If indications for confirmation of the theoretical model will be found, the three dimensions will be tested more specifically, using a pad analysis like AMOS or Lisrell (Hox 1999). However, when no clear confirmation is found, separate factor analyses, one for each of the theoretical factors will be carried out to determine whether the separate constructs of autonomy, relatedness and competence are one-dimensional (Hox 1999). If this second step does not give an indication on confirming the dimensions, the factors will be redefined based on the results of an analysis using items from the extended questionnaire. For that purpose, also PCA extraction and a varimax rotation is used.

\section{Results}




\section{Step 1. Factor analysis with a forced three factor outcome}

The factor analysis (PCA) with a forced three factor outcome using a varimax rotation on the results of the 21 items is carried out on the data of the student teachers $(n=271)$ who filled in the questionnaire in 2008 and results in a percentage of explained variance of 36.64 distributed over three factors (Table 2). The percentages of the explained variance are 14.71, 11.64, and 10.29 for relatedness, autonomy and competence respectively.

\section{INSERT TABLE 2 HERE}

In Table 2, factor loadings above .40 are printed in bold letter type. Eight items load on the first factor, with one below .40. From these eight items, five with loadings above .40 refer to the construct of relatedness: 'When we work together, I get along well with my fellow students', 'When we work together my fellow students take me seriously', 'In the teacher education course, I get along with the people I come into contact with', 'When we work together, I get positive feedback from my fellow students' and 'In the teacher education course I have too little social contacts'. The other two refer to the theoretical construct of autonomy ('When we work together, everyone can be themselves' and 'In the teacher education course, I can express my opinion freely'). The factor loadings of the relatednessitems, range from .82 to .41 . The loadings of the two autonomy-items are .52 and .46 . In this first factor, that only partly represents the theoretical constructs of relatedness and autonomy, the relatedness-items are dominant. So, the empirical factor (partly) confirms the theoretical one.

The second factor consists of five items with loadings ranging from .78 to .60. These items refer to a combination of the three theoretical constructs ('The study coach takes me 
seriously', 'The study coach gives me positive feedback', The study coach often gives me the feeling that I'm not doing well', 'The study coach does not seem to like me much', and 'The study coach takes my learning needs into consideration'). In other words, this factor does not confirm any of the hypothesised theoretical constructs.

The third factor consists of eight items, six with loadings above .40. From these six items, three refer to the construct of competence and three to the construct of autonomy. The competence-items ('In the teacher education course I often think: I have learned a lot', 'In the teacher education course I cannot show that I am competent' and 'In the teacher education course I learn relevant new skills') have factor loadings that range from .61 to .51 . The autonomy-items ('In the teacher education course I cannot enough decide about my learning route' , 'In the teacher education course I am free to learn things that suit my interests' and ' In the teacher education course I often have to do what I've been told') have loadings that range from .61 to .43. This empirical factor does not confirm the theoretical competencefactor.

Summarising, the results of the factor analysis do not confirm the expected theoretical structure with three factors. Therefore the decision is made to carry out three separate factor analyses.

\section{Step 2. Separate factor analyses, one for each theoretical construct}

To determine whether each of the three separate theoretical constructs consist of one latent dimension, a separate PCA is carried out for each factor (each separate PCA forced to one factor). The results are summarised below.

For the construct 'Relatedness' all five items have sufficient loadings. Together these items explain $30.95 \%$ of the variance. For the construct of autonomy also all items have sufficient loadings, the explained variance is $32.25 \%$. In other words, a latent dimension is 
found in the results of the relatedness and the autonomy-items. However, when tested on reliability, Cronbach's Alpha's amount to .59 and .47 respectively, not enough to make up scales. For the construct of competence five of the six items have sufficient loadings, an explained variance of $29.47 \%$, yet Cronbach's Alpha is insufficient (.46).

The results of the separate factor analyses, confirm -to a certain extent- the theoretical constructs. But the reliability of the three scales is not sufficient. There were no possibilities to increase the Alpha's by removing items from the scales.

\section{Step 3: Exploring other items for valid scale construction}

Because the extended questionnaire consists of 52 items it is possible to look for operationalisations that are more appropriate in the specific context of Dutch student teacher education. In order to construct valid scales, the next procedure is followed. All possible relevant items for each construct (between 10 and 12 items each) were taken from the extended questionnaire and put into a PCA, in order to determine a new factor, based on factor loadings with a minimum of .40 . These items are put into a reliability analysis to determine the homogeneity of the scale. To reach sufficient reliability score, items will be removed, if necessary. The results are discussed below. Only items with sufficient loadings are mentioned.

\section{Relatedness scale}

The extended questionnaire contains 10 items that refer to the construct of relatedness. Exploring these items in a PCA we found a factor consisting of six items, two phrased positively and four negatively with an explained variance of $37.51 \%$. Two positive items correspond with Deci and Ryan's operationalisation, namely 'In teacher education course I get along with my fellow student teachers' and 'When we work together fellow student 
teachers take me seriously'. Two of the negative items correspond with the original BPNS: 'In teacher education course I am very much on my own' and 'In teacher education course I get to little social contacts'. The other two negative items do not correspond with Deci and Ryan's operationalisation. These items are: 'When we work together I mostly work alone' and 'When we work together other student rather not work with me'. The six items together constitute a scale (Cronbach's Alpha is .63).

\section{Autonomy scale}

Using all 12 items that refer to the autonomy construct in a PCA, results in a factor consisting of nine items with loadings above .40 and an explained variance of $24.86 \%$. When a reliability analysis is carried out, four items remain (Cronbach's Alpha is .64). This scale consists of two positively and two negatively phrased items. These items are an operationalisation of autonomy with regard to having influence on the content of the course and autonomy in the context of collaboration with other students. This scale consists of two new items ('In teachers education course I can learn things that fit my interests' and 'When we work together I do not get a chance to determine what I want to learn') and two items that correspond with the original BPNS ('In the teachers education course I feel free to create a study path that suits me' and 'In the teacher education course I cannot enough decide about my learning route').

\section{Competence scale}

Using all 10 items related to the construct of competence in a PCA, six items constitute a factor with loadings above .40 and an explained variance of $26.34 \%$. Four items are phrased positively, two negatively. Putting these six items into a reliability analysis, the four positively phrased items consitute a reliable scale (Cronbach's Alpha is .72). 
This scale consists of two items that correspond with the original BPNS, namely 'In teacher education course I learn relevant new skills' and 'In teacher education course I often think: 'I have learned a lot', and two new items 'In the teacher education course I develop many insights on education' and 'when we work together I learn interesting new things'.

The results, shown in Table 3 point out that three separate factors can be distinguished in a overall factor analysis, each of them referring to one of the theoretical constructs, together explaining $47.11 \%$ of the variance.

\section{INSERT TABLE 3 HERE}

The correlations between the 14 items (six relatedness, four autonomy and four competence items) are presented in Table 4. This table shows relatively high correlations between items that load on the same factor and relatively low correlations of items that load on different factors.

\section{INSERT TABLE 4 HERE}

Table 5 shows that the correlations between the separate scales are significant but low. This indicates that, however these three scales refer to a common construct (i.e. need fulfilment in teacher education), each separate scale measures a specific aspect of this construct, namely the fulfilment of a specific basic psychological need (relatedness, competence and autonomy). 
Finally we determined whether these three factors comprised sufficiently reliable scales when used in a sample of other students $(n=222)$, one year later. Table 5 shows similar Alpha's for both groups, in the second group ranging from .64 to .71. Each separate scale refers to one dimension and contains enough items to measure the construct. The constructs of relatedness, autonomy and competence can be measured reliably in a student teacher population with this questionnaire.

INSERT TABLE 6 HERE

\section{Conclusions and discussion}

The need for a reliable and easily usable instrument for measuring basic psychological need fulfilment in student teachers, required a search composed of three steps.

The results of the factor analysis in step 1 (see Table 2) provided insufficient evidence that the three dimensions, as postulated by Deci and Ryan, are measured reliably with the questionnaire for student teachers. As a result of this outcome step 2 was necessary, namely an analysis of each separate dimension. The PCA per theoretical construct results in a structure with three different factors, but was not good enough to establish valid scales in the reliability analysis. In step 3 for each latent dimension, an exploratory factor analysis (PCA) on a broader range of items was carried out. This exploratory factor analysis provided three factors consisting of six items for relatedness, four for autonomy and four for competence. Reliability analysis points out that each of these scales consist of a sufficient number of items and are internally consistent. These findings were confirmed by the results of a PCA on a new set of data. 
Although the results of this study give support to Deci and Ryans model of three basic psychological needs, it is important to keep in mind that the data were gathered in a selective sample of teacher education institutes. Further research in broader and more representative samples should be carried out to confirm our findings. Furthermore, in the constructing the questionnaire, we have build on previous knowledge on intrinsic motivation on learning and development in relation to basic psychological need fulfilment. Further research should be carried out to establish these relation for the specific population of student teachers. And finally, we did not take the organisational and individual conditions into account which could influence basic psychological need fulfilment. More research on these relations can reveal insights that will be helpful in enhancing student teachers' intrinsic motivation.

This study yields some interesting practical implications. Using the scales in combination with more qualitative methods (like semi-structured interviews) can be helpful in measuring student teachers' perceptions of basic psychological need fulfilment in teacher education courses. On the basis of the data, collected by this instrument, study coaches and student teachers can have informed discussions that enlarge their understanding of the student teachers' perceived need fulfilment and intrinsic motivation in the context of the teacher education course. On the basis of the outcomes of these discussions, student teachers and study coaches can jointly set classroom goals that accommodate the student teachers' basic needs and enhances their learning. See Parker and Hess (2001) for a useful typology of classroom discussion within the context of teacher education. Using the data in this way, student teachers, facilitated by their study coaches, can be challenged to carry out a shared inquiry into their own motivational and learning processes. Study coaches can play an important role in framing the actions the student teachers have decided on, as serving the fulfilment of their basic psychological needs. As can be expected this intrinsic goal framing 
will promote deeper processing of the learning material and greater conceptual understanding (Vansteenkiste et al. 2006, p.28).

Besides the relevance for the student teachers themselves, this approach can prepare them for teaching practice in a very meaningful way. Not only will the student teachers experience the relevance of a shared classroom inquiry into their own basic psychological needs themselves, they are also offered opportunities to acquire relevant theoretical concepts that can deepen their understanding of learning and motivational processes in their own (future) students, and enlarge the competencies that enable them to have stimulating studentteacher conversations with their (future) classes.

Finally, thanks to its practicality (qualitative data, 14 five-point items) the questionnaire can easily be implemented in teacher education institutes for purposes of quality management, which is (as stated above) common practice in the Netherlands. On the basis of repeated measurements, trends can be revealed and comparisons can be made between departments and classes, serving as basis for a classroom dialogue as well as providing an informed ground for goal setting and generating actions that stimulate intrinsic motivation for learning in day to day practice on the institution's level. 


\section{References}

Baard, P. P., Deci, E. L., and Ryan, R. M. 2004. Intrinsic need satisfaction: A motivational basis of performance and well-being in two work settings. Journal of Applied Social Psychology, no. 34: 2045-2068.

Bandura, A. 1997. Self-efficacy: The exercise of control. New York: W.F. Freeman and Company.

Bandura, A., and Schunk, D.H. 1981. Cultivation competence, self-efficacy and intrinsic interest through proximal self-motivation. Journal of Personality and Social Psychology 41, no. 3: 586-598.

Reference deleted to maintain the integrity of the review process

Deci, E.L. 1975. Intrinsic Motivation. New York: Plenum.

Deci, E.L., and Ryan, R.M. 1985. Intrinsic Motivation and Self-Determination in Human Behaviour. New York: Plenum.

Deci, E.L., and Ryan, R.M. 2000. The 'What' and 'Why' of Goal Pursuits: Human Needs and the Self-Determination of Behaviour. Psychological Inquiry, no. 11: 227-268.

Deci, E.L., and Ryan, R.M. (Eds.). 2002. Handbook of self-determination research. Rochester, NY: University of Rochester Press. 
Deci, E.L., and Ryan, R.M. 2008. Self-determination theory: A macrotheory of human motivation, development ans health. Canadian Psychology, no. 49: 182-185.

Deci, E.L., and Vansteenkiste, M. 2004. Self-determination theory and basic need satisfaction: Understanding human development in positive psychology. Richerche di Psichologica, no. 27: 17-34.

Evelein, F., Korthagen, F.A.J., and Brekelmans, M. 2008. Fulfilment of the basic psychological needs of student teachers during their first teaching experiences. Teaching and Teacher Education, no. 24: 5, 1137-1148.

Filak, V. F., and Sheldon, K. M. 2003. Student psychological need-satisfaction and college teacher-course evaluations. Educational Psychology, no. 23: 235-247.

Garson, G.D. 2007 Quantitative Research in Public Administration Syllabus for PA 765 766 http://factulty.chass.ncsu.edu/garson/PA765/factor.htm.

Gough, S. 2008. Co-evolution, Knowledge and Education: Adding Value to Learners' Options. Studies in Philosophy and Education, no. 1: 1-12.

Guba, E.G., and Lincoln, Y.S. 1989. Fourth generation evaluation. Newbury Park: Sage.

Hagger, M. S., \& Chatzisarantis, N. L. 2007. Intrinsic motivation and self-determination in exercise and sport. Champaigne, IL: Human Kinetics. 
Hox, J. J. 1999. Principes en toepassing van structurele modellen [Principles and application of structural models] . In: Kind en Adolescent [Child and Adolescent], no 20: 200-217.

Kohn, A. 1999. Punished by rewards. Boston/New York: Houghton Mifflin Company

Lepper, M.R., Greene, D., and Nisbett, R.E. 1973. Undermining children's intrinsic interest with extrinsic rewards: A test of the 'overjustification' hypothesis. Journal of Personality and Social Psychology, no.18: 129-137.

Martens, R.L. 2007. Positive learning met multimedia. Onderzoeken, toepassen \& generaliseren [Positive learning with multimedia. Researching, applying and generalizing]. Heerlen: Open Universiteit.

Oost, H. 1999. De kwaliteit van probleemstellingen in dissertaties. [The quality of research problems in dissertations. Utrecht: Universiteit Utrecht.

Parker, W.C., and Hess, D. 2001. Teaching with and for discussion. Teacher and Teacher Education, no. 17: 273-289.

Putnam, L. 2010. Communication as Changing the Negotiation Game. Journal of Applied Communication Research, no. 4: 325-335 
Reise, S.P., Widaman, K.E. and Pugh, R.H. 1993. Confirmatory factor analysis and item respons theorie. Two separate approaches for exploring measurement invariance. Psychological Bulletin, no. 114: 552-566

Roth, G., Assor, A., Kanat-Maymon, Y., and Kaplan, H. 2007. Autonomous Motivation for Teaching: How Self-Determined Teaching May Lead to Self-Determined Learning. Journal of Educational Psychology, no. 4: 761-774

Roness, D., and Smith, K. 2010. Stability in motivation during teacher education. Journal of Education for Teaching: International Research and Pedagogy, no. 2: 169-185.

Ryan, R.M. 1995. Psychological Needs and the facilitation of integrative processes. Journal of Personality, no. 63: 397-427

Ryan, R.M., and Connell, J.P. 1989. Perceived Locus of Causality and Internalization: Examining Reasons for Acting in Two Domains. Journal of Personality and Social Psychology, 5, 749-761

Ryan, R.M., and Deci, E.L. 2000. Self-Determination Theory and the Facilitation of Intrinsic Motivation, Social Development and Well-Being. American Psychologist, no. 55: 68-78.

Ryan, R.M., and Deci, E.L. 2004. Autonomy is no illusion: Self-determination theory and the empirical study of authenticity, awareness and will. In Handbook of experimental existential psychology, eds. J. Greenberg, S.J. Koole, and T. Pyszczynski, 449-479. New York: Guilford Press. 
Ryan, R.M., and Deci, E.L. 2006. Self-regulation and the problem of human autonomy: Does psychology need choice, self-determination and will? Journal of Personality no. 74: 15571586.

Ryan, R. M., Lynch, M. F., Vansteenkiste, M., \& Deci, E. L. 2010. Motivation and autonomy in counseling, psychotherapy, and behavior change: A look at theory and practice. The Counseling Psychologist, no. 32: 193-260.

Schuman, H. 1996. Questions and answers in attitude surveys: Experiments on question form, wording, and context. Thousand Oaks: Sage Publications

Schunk, D.H., and Pajares, F. 2007. Competence Perceptions and Academic Functioning.In Handbook of Competence and Motivation, eds. A.J. Elliot and C.S. Dweck, 85-104. London: The Guilford Press.

Sheldon, K.M., and Elliot, A.J. 1998. Not all personal goals are 'personal': Comparing autonomous and controlling goals on effort and attainment. Personality and Social Psychology Bulletin, no. 24: 546-557.

Stevens, L.M. 1997. Over denken en doen. Een pedagogische bijdrage aan adaptief onderwijs [About thinking and acting. A pedagogical contribution to adaptive education]. 'sGravenhage: PMPO 
Vansteenkiste, M., Lens, W. and Deci, E.L. 2006. Intrinsic versus extrinsic goal contents in self-determination theory: Another look at the quality of academic motivation. Educational Psychologist, no. 41: 19-31.

Vansteenkiste, M., Soenens, B., Verstruyf, J., and Lens, W. 2009. What is the usefulness of your schoolwork? The differential effects of intrinsic and extrinsic goal framing on optimal learning. Theory and Research in Education, no. 7:155-163.

Williams, G. C., McGregor, H. A., King, D., Nelson, C. C., \& Glasgow, R. E. 2005. Variation in perceived competence, glycemic control, and patient satisfaction: Relationship to autonomy support from physicians. Patient Education and Counseling, no. 57: 39-45. 
Table 1

Response

\begin{tabular}{lc}
\hline $\begin{array}{l}\text { Teacher education } \\
\text { institute }\end{array}$ & $\begin{array}{l}\text { Number of } \\
\text { student teachers }\end{array}$ \\
\hline D & 74 \\
K & 45 \\
M & 37 \\
I & 11 \\
Z & 104 \\
\hline Total & 271 \\
\hline
\end{tabular}


Table 2

Factor analysis and the loadings per item extraction principal component analyses with varimax rotation with forced 3 factor of BPNS Deci and Ryan (n=271). (r= relatedness, a= autonomy, $c=$ competence)

\begin{tabular}{|c|c|c|c|c|c|}
\hline & & & \multicolumn{3}{|c|}{ Component } \\
\hline & & & 1 & 2 & 3 \\
\hline r & \multicolumn{2}{|c|}{ When we work together I get along with my fellow student teachers. } & ,823 & 077 & ,094 \\
\hline$r$ & \multirow{3}{*}{\multicolumn{2}{|c|}{$\begin{array}{l}\text { When we work together my fellow students take me seriously. } \\
\text { In the teacher education course I get along with the people I come } \\
\text { into contact with. } \\
\text { When we work together, everyone can be themselves }\end{array}$}} & ,653 &,- 020 &,- 051 \\
\hline r & & & 635 &,- 036 &,- 172 \\
\hline a & & &, 520 &, 131 &,- 118 \\
\hline a & \multicolumn{2}{|c|}{ In the teacher education course I can express my opinion freely. } & ,463 & 085 &,- 371 \\
\hline$r$ & \multicolumn{2}{|c|}{$\begin{array}{l}\text { When we work together I get positive feedback from my fellow } \\
\text { students }\end{array}$} & ,459 & 159 &, 008 \\
\hline r & \multicolumn{2}{|c|}{ In the teacher education course I have too little social contacts. } &,- 410 &,- 010 & ,287 \\
\hline r & \multicolumn{2}{|c|}{ In the teacher education course I am very much on my own. } &,- 376 & ,026 & ,041 \\
\hline a & \multicolumn{2}{|c|}{ The study coach takes me seriously. } &, 044 & ,781 &,- 001 \\
\hline r & \multicolumn{2}{|c|}{ The study coach gives me positive feedback. } &,- 045 & ,765 & ,009 \\
\hline c & \multicolumn{2}{|c|}{ The study coach often gives me the feeling that I'm not doing well. } &,- 136 &,- 663 & ,131 \\
\hline $\mathrm{r}$ & \multicolumn{2}{|c|}{ The study coach doesn't seem to like me much. } &,- 103 &,- 612 & ,250 \\
\hline a & \multirow{2}{*}{\multicolumn{2}{|c|}{$\begin{array}{l}\text { The study coach takes my learning needs into consideration. } \\
\text { In the teacher education course I cannot enough decide about my } \\
\text { learning route. }\end{array}$}} & ,068 & ,604 &,- 104 \\
\hline a & & &,- 011 &,- 077 &, 610 \\
\hline c & \multicolumn{2}{|c|}{ In the teacher education course I often think: 'I have learned a lot'. } &,- 033 & ,105 &,- 606 \\
\hline c & \multicolumn{2}{|c|}{ In the teacher education course I cannot show that I am competent. } &,- 101 & ,023 &, 565 \\
\hline c & \multicolumn{2}{|c|}{ In the teacher education course I learn relevant new skills. } & ,007 & ,096 &,- 506 \\
\hline a & \multicolumn{2}{|c|}{$\begin{array}{l}\text { In the teacher education course I am free to learn things that suit my } \\
\text { interests. }\end{array}$} &, 061 &,- 035 &,- 492 \\
\hline a & \multicolumn{2}{|c|}{$\begin{array}{l}\text { In the teacher education course I often have to do what l've been } \\
\text { told. }\end{array}$} &,- 023 &,- 243 & ,429 \\
\hline a & \multicolumn{2}{|c|}{ In the teacher education course I often fee I pressured. } &,- 244 &,- 066 & ,348 \\
\hline c & \multicolumn{2}{|c|}{ When we work together I feel less capable than my fellow students. } &,- 183 &,- 134 & ,211 \\
\hline & Component & $\begin{array}{l}\text { Explained variance } \\
\left(R^{2}\right)\end{array}$ & & & \\
\hline 1 & & 14,71 & & & \\
\hline 2 & & $26,35(11,64)$ & & & \\
\hline 3 & & $36,64(10,29)$ & & & \\
\hline
\end{tabular}


Table 3

Factor analysis on the new scales of relatedness, autonomy and competence (PCA, Varimax, $n=271$ ) .

\begin{tabular}{|c|c|c|c|c|}
\hline & & \multicolumn{3}{|c|}{ Component } \\
\hline & & 1 & 2 & 3 \\
\hline$r$ & When we work together I do most of the things on my own & ,628 & 224 &,- 025 \\
\hline r & $\begin{array}{l}\text { When we work together fellow students rather not work with } \\
\text { me }\end{array}$ & ,616 &,- 035 & ,063 \\
\hline$r$ & $\begin{array}{l}\text { In the teacher education course I get along with my fellow } \\
\text { student teachers. }\end{array}$ & ,600 & 051 & 071 \\
\hline r & When we work together my fellow students take me seriously. & ,599 & ,037 & 079, \\
\hline $\mathrm{r}$ & In the teacher education course I am very much on my own. &, 582 & ,114 &,- 173 \\
\hline r & In the teacher education course I have too little social contacts. &, 542 & 080 & ,131 \\
\hline c & In the teacher education course I learn relevant new skills. & ,052 & ,789 &,- 013 \\
\hline c & $\begin{array}{l}\text { In the teacher education course I often think: 'I have learned a } \\
\text { lot'. }\end{array}$ &,- 028 & ,754 & , 136 \\
\hline c & When we work together I learn interesting new things & ,204 & ,715 & ,072 \\
\hline c & When working together I often think 'I have learned a lot'. & 255, & 607, & 352, \\
\hline a & $\begin{array}{l}\text { In the teachers education course I feel free to create a study } \\
\text { path that suits me. } \\
\text { In teachers education course I can learn things that fits my }\end{array}$ & ,013 & 091 & ,782 \\
\hline a & interests &,- 099 & ,067 & ,707 \\
\hline a & $\begin{array}{l}\text { When we work together I cannot enough decide about the } \\
\text { things I want to learn } \\
\text { When we work together I do not get a change to determine }\end{array}$ &,- 031 &,- 202 &,- 653 \\
\hline a & what I want to learn &,- 236 & ,005 &,- 589 \\
\hline
\end{tabular}

\begin{tabular}{lll}
\hline & component & $\begin{array}{l}\text { Explained variance } \\
\left(\mathrm{R}^{2}\right)\end{array}$ \\
\hline 1 & Relatedness & 16,44 \\
2 & Competence & $31,15(15,71)$ \\
3 & Autonomy & $47,11(14,96)$ \\
\hline
\end{tabular}




\begin{tabular}{|c|c|c|c|c|c|c|c|c|c|c|c|c|c|}
\hline & \multicolumn{4}{|c|}{ competence } & \multicolumn{4}{|c|}{ autonomy } & \multicolumn{5}{|c|}{ relatedness } \\
\hline & 1 & 2 & 3 & 4 & 5 & 6 & 7 & 8 & 9 & 10 & 11 & 12 & 13 \\
\hline 1. the teacher education course I often think: 'I have learned a lot' & & & & & & & & & & & & & \\
\hline 2. In the teacher education course I learn relevant new skills & ,48 & & & & & & & & & & & & \\
\hline 3. When we work together I learn interesting new things, & ,29 & ,42 & & & & & & & & & & & \\
\hline 4. When working together I often think 'I have learned a lot', &, 45 & ,26 &, 53 & & & & & & & & & & \\
\hline $\begin{array}{l}\text { 5. In the teacher education course I cannot enough decide about my learning } \\
\text { route }\end{array}$ &,- 16 &,- 19 &,- 19 &,- 24 & & & & & & & & & \\
\hline $\begin{array}{l}\text { 6. In the teachers education course I feel free to create a study path that suits } \\
\text { me, }\end{array}$ & ,16 & ,14 & ns & ,25 &,- 46 & & & & & & & & \\
\hline 7. In teachers education course I can learn things that fits my interests & ,21 & ns & ns & ,22 &,- 29 & ,44 & & & & & & & \\
\hline $\begin{array}{l}\text { 8. When we work together I cannot enough decide about the things I want to } \\
\text { learn }\end{array}$ & ns & ns & ns &,- 31 & ,27 &,- 28 & ,22 & & & & & & \\
\hline 9. When we work together my fellow students take me seriously, & ns & ns & ,14 & 30 & ns & ns & ns &,- 16 & & & & & \\
\hline $\begin{array}{l}\text { 10. In the teacher education course I get along with my fellow student } \\
\text { teachers, }\end{array}$ & ns & ns & ,14 & ,18 & ns & ns & ns & ns & ,26 & & & & \\
\hline 11. In the teacher education course I have too little social contacts, & ns & ns &,- 14 &,- 16 & ns & ns & ns & ns &,- 18 &,- 32 & & & \\
\hline 12. When we work together fellow students rather not work with me & ns & ns & ns & ns & ,17 & ns & ns & ,16 &,- 43 &,- 15 & ,25 & & \\
\hline 13. When we work together I do most of the things on my own &,- 16 &,- 17 &,- 23 &,- 22 & ns & ns & ns & 13 &,- 19 &,- 26 & ,27 & ,27 & \\
\hline 14. In the teacher education course I am very much on my own,, & ns &,- 14 & ns & ns & ns & ns & ns & ns &,- 20 & -.27 & 21 & ns & ,35 \\
\hline
\end{tabular}


Table 5

Correlations between the three scales relatedness, autonomy and competence $(n=271)$

\begin{tabular}{lll}
\hline & relatedness & autonomy \\
\hline relatedness &, $17^{\star \star}$ & \\
autonomy &, $26^{\star \star}$ &, $30^{* *}$ \\
competence &
\end{tabular}

${ }^{* \star}$. Correlation is significant at the 0.01 level (2-tailed). 
Table 6

Internal consistency of the scales, reliability analysis with Cronbach's Alpha

\begin{tabular}{lllllll}
\hline Scale & relatedness & & Autonomy & \multicolumn{3}{c}{ Competence } \\
\hline & Items & alpha & items & Alpha & items & Alpha \\
$2008(\mathrm{n}=271)$ & 6 & .628 & 4 & .724 & 4 & .754 \\
$2009(\mathrm{n}=222)$ & 5 & .641 & 4 & .705 & 4 & .726 \\
\hline
\end{tabular}

